\section{Why use BST?}

SIR - According to a recent News story (Nature 368, 384; 1994), Monsanto Company has sued two dairies that characterized their products as coming from cows not treated with bovine somatotropin (BST), claiming that milk from such animals is compositionally indistinguishable from the milk of BST-treated cows. Presumably the BST does not show up in the milk.

But milk is complex, and it is virtually impossible to confirm that trace components are unaffected by BST treatment. Immunologically active steroids and proteins (such as TGF $\beta$ ) are present at low but biologically significant concentrations. Several dozen biologically active components have been identified. Even if these agents are found to be unaffected by BST, there remain factors that are not yet characterized or possibly even discovered.

For example, a few years ago we stumbled upon an immunosuppressive factor in human and bovine colostrum (not in later milk) with profound effects on cellular immune responses in vitro, but that cannot be accounted for by known agents This factor is at present only partially characterized but can be detected by bioassays.

There is no difficulty, in advanced countries, in producing enough milk by the conventional method. In fact, our ability to produce far outstrips our ability to consume. And the argument that recombinant BST can lower the price of the end-product is unproven and unlikely. Most of the pennies saved by the producer will have to be paid to the masters of the technology. Many important problems cry out for technological solutions. But if a new technology isn't necessary, and we can't measure the outcome, why do it?

Verner Paetkau

Department of Biochemistry

University of Alberta,

Edmonton, Alberta,

Canada T6G $2 \mathrm{HT}$

\section{Quis custodiet?}

SIR - Fernando Aiuti recently described the impediments to the appointment of full professors in Italy (Nature 367, 590; 1994). However, one of the most important faults in Italian academic institutions could well explain the failure of competitions (concorsi): who controls whom?

Contrary to the procedure in other countries, once a professor has been appointed (won his cattedra) there is no control of his scientific activity and publications, so professors can stop their research work and publications without risking their appointment. They become 'untouchable' and during their tenure (un- til the age of 70 to 72 ) their scientific expertise may well fall below that of the future candidates. These professors cannot be expected to be sufficiently knowledgeable to select candidates on the basis of the best current scientific knowledge. When such a professor is in turn appointed to the concorso examining committee, he will be less willing to accept the candidate's international scientific credentials. So a vicious circle begins through which the lack of scientific credentials in the examining committees leads to the appointment of more poorly qualified professors.

One example is the 1989 concorso for full professor in pulmonary disease. Incredibly, this competition has now been going on for five years. Of the five members of the examining committee, only those with the best scientific credentials are able to appreciate the best candidates, while less qualified members tend to use the 'old boy' network. The candidates unfairly excluded have applied to the courts for justice but, although the competition was declared invalid by the Corte dei Conti (public affairs control court), the examining committee of that concorso stays the same. The Ministry of Universities so far has not been able to replace the committee of 'untouchables' or guarantee the teaching of pneumology in the universities that had originally asked for a professor in this subject. Who controls whom?

\section{Tommaso Todisco}

Pulmonary Unit,

R. Silvestrini Hospital,

O6132 Perugia,

Italy

\section{Nuclear weapons}

SIR - The US refusal to export highly enriched uranium to Germany should be seen as a welcome contribution to nonproliferation (Nature 369,$85 ;$ 1994). In view of the stringency with which this policy is being pursued, it is surprising that the United States has not taken any action on THORP in the United Kingdom, which will provide weapons-usable plutonium to Germany, among others, and is looking to supply mixed oxide (MOX) fuel as well

You say the material will be subject to whatever safeguards are needed to ensure that it is not diverted to military uses. But safeguards have proved inadequate even in 'law-abiding' countries such as Japan, where it was recently disclosed that $70 \mathrm{~kg}$ of plutonium are unaccounted for, presumed stuck in process equipment.

The sooner the close links between nuclear power and nuclear weapons are acknowledged the better. The "inalienable right' to nuclear technology granted under the Non-Proliferation Treaty (NPT) has been, and is being, exploited for less than peaceful purposes by countries that many would rather not see having a nuclear capability.

As far as the Campaign for Nuclear Disarmament (CND) is aware, the question of access to 'peaceful' nuclear technology is not the foremost concern of the non-nuclear NPT signatory states. On the contrary, their principal objections to the NPT as it stands are that the nuclear states have neglected their side of the bargain, that is, to pursue disarmament in good faith.

It is for this reason that CND advocates only a limited extension of the NPT, conditional on moves towards a global treaty banning all nuclear weapons. Part of CND's agenda, summed up in its Blueprint for a Nuclear-Weapon-Free World is a call for the establishment of an international fund to investigate, promote and invest in sustainable alternatives to nuclear power.

The only way to ensure that nuclear technology is not misused is to replace it, rather as the United States is trying to do with highly enriched uranium in Germany.

\section{Janet Bloomfield}

(Chair)

Campaign for Nuclear Disarmament,

162 Holloway Road,

London N7 8DQ, UK

\section{Rough justice}

SIR - It is open to anyone to write an anonymous letter accusing a scientist of faking his or her data. But one would not expect a reputable publication to print the accusation in the absence of evidence to support the claim.

In the case of Dr Justine Sergent, the Montreal Gazette did not feel it necessary to operate under this constraint. Neither, apparently, did McGill University find it necessary to demand that the Gazette publish an immediate apology (Nature 369, 176; 1994)

Those of us who were Justine's friends find the accusation against her unbelievable; but whatever the outcome of the inquiries currently in progress, academic justice, like every other variety, should surely rest on the principle of innocent until proved guilty. The evidence presented to all the McGill inquiries must be made public as soon as possible; the ethical standards of more people than Justine Sergent are at issue.

\section{John C. Marshall}

Jennifer M. Gurd

Neuropsychology Unit,

University Department of Clinical

Neurology,

Radcliffe Infirmary,

Woodstock Road,

Oxford OX2 $6 \mathrm{HE}$, UK 